\title{
Doğuştan çarpık ayak: eksternal fiksatör uygulaması
}

\section{Congenital clubfoot: correction with external fixators}

\author{
İlker Sarıkaya ${ }^{1}$, Mehmet Ali Talmaç², Muharrem İnan ${ }^{3}$ \\ ${ }^{1}$ Çocuk Ortopedi Kliniği, Şişli, İstanbul \\ ${ }^{2}$ Şişli Etfal Ĕgitim ve Araştırma Hastanesi, Hamidiye, İstanbul \\ 3̇stanbul Üniversitesi Cerahpaşa Tıp Fakültesi, Ortopedi ve Travmatoloji Anabilim Dalı, İstanbul
}

\begin{abstract}
Doğuştan çarpık ayak tedavisinde amaç, tabanı yere basabilen, hareketli ve ağrısız bir ayak elde edilmesidir. Bu amaca ulaşmanın her olguda kolay olmaması, konvansiyonel yöntemlerin zaman zaman tekrarlayan geniş yumuşak doku ve kemik cerrahilerini içeriyor olmaları ve yüksek nüks oranları göz önüne alındığında, eksternal fiksatör ile tedrici düzeltme, alternatif tedavi metodu olarak karşımıza çıkmaktadır. Bu yöntemin avantajları; aynı anda birçok deformitenin düzeltilebilmesine olanak sağlaması, diğer yöntemlere nazaran daha az invaziv olması, osteotomilerle ve yumuşak doku cerrahileriyle kombine edilebilmesi, ayak boyutunu küçültmemesi ve erken yük vermeyi mümkün kılması olarak sayılabilir. Tedavide yaşanması olası başlıca güçlükler ve komplikasyonlar ise; uzun tedavi süresi, pin dibi enfeksiyonu, distraksiyonun yarattığı ağı ve hareket kısıtlılığıdır.
\end{abstract}

Anahtar sözcükler: çarpık ayak; doğumsal kusurlar; eksternal fiksatör, sirküler; distraksiyon, tedrici; nekroz, cilt
The aim of the treatment of congenital clubfoot is to obtain a foot which is fully corrected, plantigrade, mobile and painless. Because conventional methods require repeated extensile soft tissue surgeries and osteotomies, have high recurrence rates, and it is not too easy to obtain these conditions for every case, gradual distraction and correction with external fixator is presented as an alternative treatment method. One of the advantages of this method is that it allows the correction of the deformity in multiple planes. Also, this method is minimal invasive, can combine with osteotomies and soft tissue surgeries, preserve foot size, and allows early weight bearing. The difficulties and complications of treatment are: prolonged treatment period, pin tract infection, pain caused by distraction and joint motion restriction.

Key words: clubfoot; congenital defects; external fixators, circular; distraction, gradual; necrosis, skin
P onseti metodu, günümüzde doğuştan çarpık ayak tedavisinde başarısı kanıtlanmış ve yaygın olarak kullanılan tedavi yöntemidir. ${ }^{[1]}$ Ancak, Ponseti metodunun \%20 oranına başarısızlığa sahip olduğu, tedavisi ihmal edilmiş olgular ya da artrogripozis gibi bir sendromun eşlik ettiği tedavisi güç durumlar göz önüne alındığında, doğuştan çarpık ayak tedavisinde başka yöntemlere ihtiyaç duyulduğu aşikardır. ${ }^{[2]}$ Böyle olgularda cerrahi yöntemlere başvurulduğu, ancak \%20-65 gibi yüksek nüks oranlarının da tedavi sürecinin bir parçası olabileceği bilinmektedir. [3] Ayrıca, tekrarlayan yumuşak doku girişimlerinin büyük cilt skarları içermesi, cilt nekrozu gibi sorunlar doğurabilir. Osteotomi ya da yumuşak dokuya yönelik yöntemlerle deformitenin akut düzeltilmesi, özellikle skar dokularla sarılı durumda olan nörovasküler yapılara yönelik tehlike arz eder. Yukarıda sayılanlara ek olarak, ayağa yönelik gerek osteotomiler gerekse de artrodezler sonucunda mevcut olan kısalığın bir nebze daha artacağı da göz önüne alındığında, ihmal edilmiş, sert bir deformiteye sahip veya nüks eden doğuştan çarpık ayak olgularında alternatif tedavi yöntemi olarak eksternal fiksatör ile tedrici düzeltme gündeme gelmektedir. ${ }^{[3]}$

Eksternal fiksatör vasıtasıyla tedrici düzeltmenin, başta damar ve sinir yapıları olmak üzere çevre kas ve yumuşak dokulardaki gerginliği belirli bir seviyenin altında tutacağı ve böylelikle nörovasküler yaralanma, cilt nekrozu gibi sorunlarla karşılaşılma olasılığını azaltacağı gösterilmiştir. ${ }^{[4]}$ Ayrıca, sirküler tipte eksternal fiksatör, birden fazla planda bileşeni olan doğuştan çarpık ayak deformitesinin aynı anda çok planda düzeltilebilmesini olanaklı hale getirmektedir. ${ }^{[5]}$ Ameliyat sonrası dönemde de, cerrahi gerekmeksizin düzeltme

- İletişim adresi: Dr. İlker Sarıkaya, Çocuk Ortopedi Kliniği, Hakkı Yeten Caddesi, Unimed Centre Kat: 9, Fulya, Şişli, İstanbul Tel: 0532 - 7329740 e-posta:drsarikayailker@gmail.com muharreminan@hotmail.com

- Geliş tarihi: 25 Mayıs 2015 Kabul tarihi: 25 Mayıs 2015 

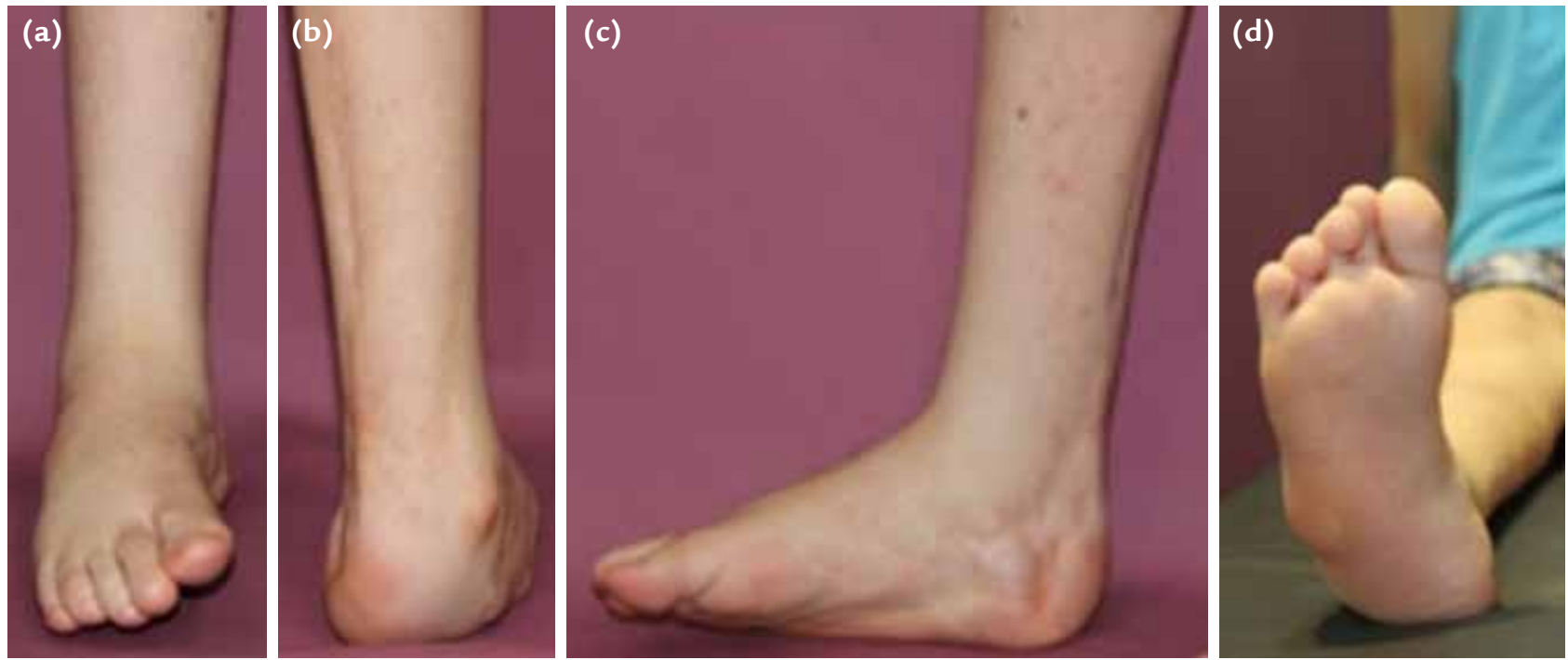

Şekil 1. a-d. Nüks etmiş doğuştan çarpık ayak olgusunun önden (a), arkadan (b), iç yandan (c) ve tabandan (d) görünümleri.

planında değişiklik yapılması mümkün olmakta ve böylelikle, aşırı ya da eksik düzeltme olasılığı da en aza indirgenmektedir. Gerek duyulan olgularda eksternal fiksatör kullanımı, beraberinde yumuşak doku ve kemik girişimlerinin uygulanabilmesine ve eşlik etmesi olası alt ekstremite deformitelerinin tedavisine de olanak sağlar. ${ }^{[4]}$ Minimal invaziv bir yöntem olarak kabul edilebilen eksternal fiksatör uygulamasıyla, ayak boyutunun küçülmesinin önüne geçilir. Ayrıca, ameliyat sonrası dönemde erken yük verilerek, ekstremitenin fonksiyonelliğini sürdürmesi de sağlanır.

\section{ENDIKASYONLAR}

Eksternal fiksatör yardımı ile doğuştan çarpık ayak tedavisi gözden geçirildiğinde, belirleyici temel unsurlardan ilki olarak yaş ön plana çıkmaktadır. Sekiz yaşından küçük olguların tedavisinde, yumuşak dokuların ve kemik yapıların büyük remodelasyon kapasiteleri sayesinde, eksternal fiksatör vasıtasıyla tedrici düzeltme yalnız başına yeterli olur. Ancak, daha büyük olgularda, kemik büyüme kapasitesinin azalmış olduğu ve eklemlerin erişkin dönemdeki pozisyonlarında konumlandıkları düşünüldüğünde, eksternal fiksatör vasıtasıyla tedrici olarak düzeltme tek başına yeterli olmayacak ve ilave yumuşak doku ve/veya kemik girişimleri de gerekecektir. ${ }^{[6]}$ Böyle olgularda, sirküler eksternal fiksatör ile deformite düzeltilirken, yumuşak doku gevşetmeleri ve tendon uzatmaları ile de ayak bileği ve ayak eklemlerinin uyumu sağlanabilir. Osteotomi ise, daha önce füzyon ya da osteotomi uygulanmış olgularda yumuşak doku girişimlerine cevap vermeyecek ölçüde sert bir deformite varsa uygulanmalıdır. Nüks doğuştan çarpık ayak olgularında sirküler tipte eksternal fiksatör uygulanmasını gerektiren temel patolojiler, ayağın arka ve orta kısmındaki ciddi sert deformitelerdir; ayak bileği posteromediyalindeki nörovasküler yapıları saran yapışıklıkların eşlik ettiği ciddi ekinovarus ve ekinokavus deformiteleri, plantigrad basmaya engel olan başlıca patolojilerdir (Şekil 1). ${ }^{5]}$

Cerrahi gevşetme uygulanacak bölgeler, temel olarak dört başlıkta toplanabilir: 1) ayak arkası ekinus deformitesine yönelik posterior, 2) ayak arkası varusuna ve ayak ortası adduktusuna yönelik mediyal (yüzeyel ve derin), 3) kavusa yönelik plantar ve 3) lateral kolonun yeniden diziliminin sağlanmasına yönelik lateral gevşetmeler. ${ }^{[6]}$

Fiksatör uygulaması esnasında uygulanan osteotomiler, temel olarak beş başlıkta toplanabilir:[1] 1) Ayak arkası ekinusu ve varusunu düzeltmeye yönelik $U$ osteotomisi ile, arkada kalkaneusta ve önde talus boynunda yarım daire şeklinde bir osteotomi gerçekleştirilir. 2) Ayak bileğinde varus, valgus adduksiyon deformitelerinin ve sert subtalar eklemin mevcut olduğu patolojilerde deformite, $V$ osteotomisi ile ayak arkasında üçgen şeklinde bir segment oluşturularak düzeltilir. $\mathrm{V}$ osteotomisinde, arka osteotomi kalkaneusta, ön osteotomi ise talus boynunda konumlanır. 3) Supramalleoler osteotomi ile, metafizyel seviyedeki ilave ekstremite uzunluk eşitsizliğinin, rotasyonel-açısal deformitelerin ve ayak arkası-önü ilişkisinin normal olduğu subtalar eklem seviyesindeki deformitelerin düzeltilmesi mümkün olur. $\left.{ }^{[7]} 4\right)$ Posterior kalkaneus osteotomisi ile, ön 


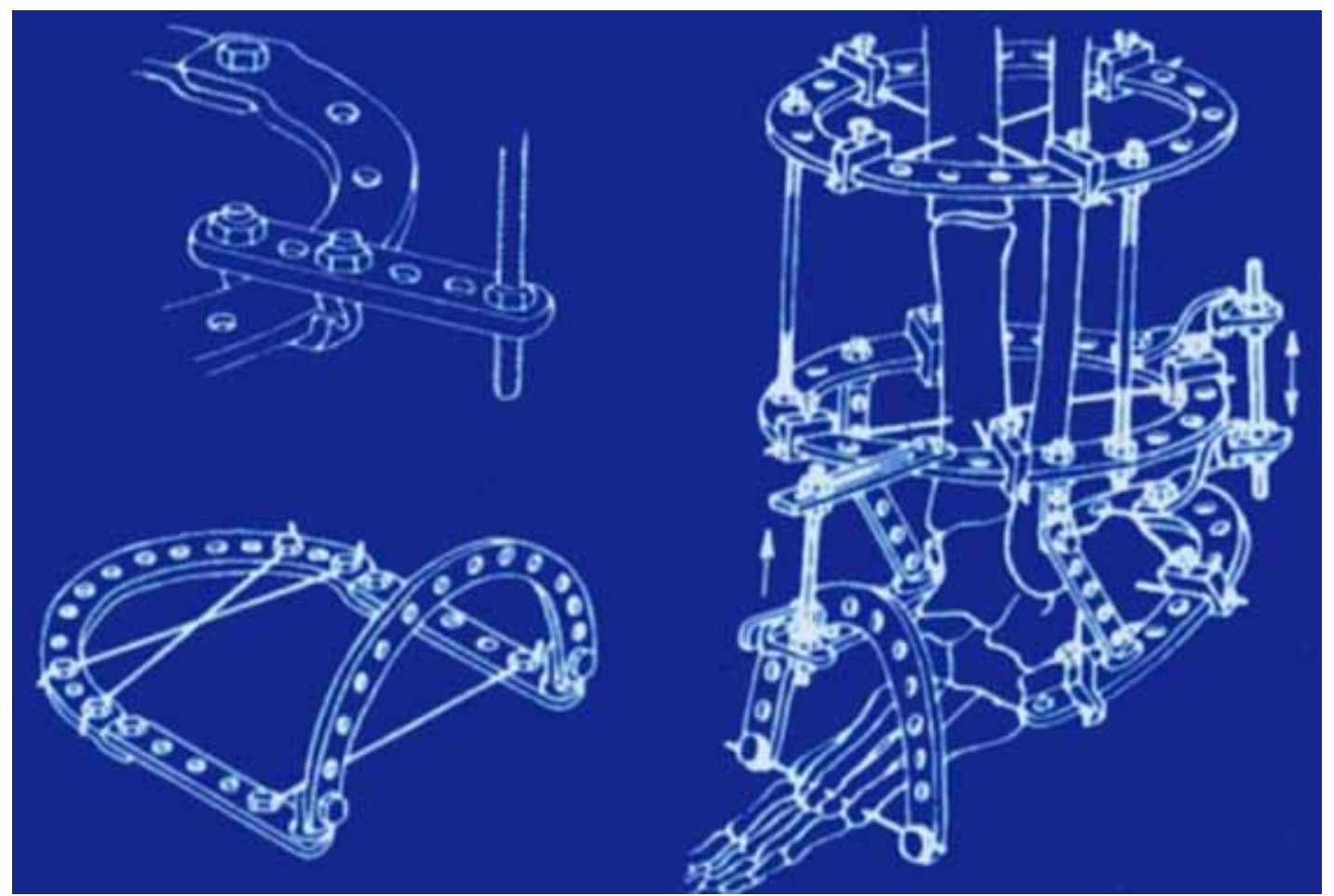

Şekil 2. Doğuştan çarpık ayak tedavisinde Ilizarov eksternal fiksatör kurulumunun şematik çizimi (Burns JK, Sullivan R. Correction of severe residual clubfoot deformity in adolescents with the llizarov technique. Foot Ankle Clin 2004; 9(3):571-82.).

ayak sorunu olmaksızın, ayak arkası izole deformiteleri düzeltilebilir. 5) Metatarsal kısalık ve deformasyonlarda, metatarsal osteotomiler uygulanabilir.

\section{CERRAHI TEKNIK}

Standart sirküler eksternal fiksatör uygulamasında, tibia uzun aksına dik birbirine paralel iki ya da üç adet halka, her halkada çapraz iki adet 1,5-2 mm çapında Kirschner teli uygulanır. Kirschner tellerine 110 newton gücünde germe kuvveti uygulanır. ${ }^{[5]}$ Kirschner tellerinin halkanın anteriorunda olmasından kaçınılmalı, mümkün olduğunca posterioruna yerleştirilmeli ve bunlar lateralden mediyale uygulanmalıdır (Şekil 2).

Topuk, kemiğin longitudinal aksına paralel bir yarım ya da $5 / 8$ halkanın iki ya da üç adet çapraz stoplu Kirschner teli ( 1,5 ya da $1,8 \mathrm{~mm}$ çapında) ve kemiğin arkasında tüberozitas kalkaneinin üzerinden ilerletilen bir Schanz çivisi ( $5 \mathrm{~mm}$ çapında) ile tespit edilir. Kirschner telleri yerleştirilirken tibialis posterior arter palpe edilmeli ve teller mediyalden laterale, nörovasküler hasara sebebiyet vermeyecek şekilde ilerletilmelidir.

Ön ayağın tespiti için, iki adet stoplu Kirschner teli (1,5 ya da $1,8 \mathrm{~mm}$ çapında) metatarslardan birbirlerine paralel olacak şekilde geçirilir ve 90 newtonluk gerim kuvvetiyle, iki adet birbirine paralel ve ön ayağın uzun aksına dik yarım ya da $5 / 8$ halka ile tespit edilir. Kirschner tellerinden biri metatars boynundan diğeri metatars cisminden, mediyalden laterale doğru ilerletilir; Kirschner tellerinin her birinin iki ya da üç metatarsı geçmesi ve bir telin birinci metatarstan beşinci metatarsa geçmesi hedeflenir.

Halkalar ve yarım halkalar, birbirlerine, ayak ve ayak bileği hareketlerine olanak sağlayacak şekilde yerleştirilen rodlar ve menteşeler ile bağlanır (Şekil 3). Tibial halkalar arasında üç ya da dört adet rod (aşağıdaki tibial halka ile kalkaneal yarım halka arasında bir, arkada birer tane lateralde ve mediyalde) bulunmalıdır. Topuk ve ayak önü yarım halkaları arasında, lateralde ve mediyalde birer rod bulunmalıdır. Ayak önü yarım halkası ile alt tibial halka arasında, bir ya da iki rod ile bağlantı sağlanmalıdır. Başlangıçta tibia ve ön ayak ön kısmı frame'leri arasında bağlantı yoktur.

Ekinus, varus, kavus ve adduksiyon deformitelerinin tamamen düzelmesini takiben, supinasyon deformitesi düzeltilir ve anteriora yerleştirilen bir rod ile tespit edilir. Supinasyon deformitesi, lateral rodun kısaltılması ve mediyal rodun uzatılması ile düzeltilir. Ayak önü 

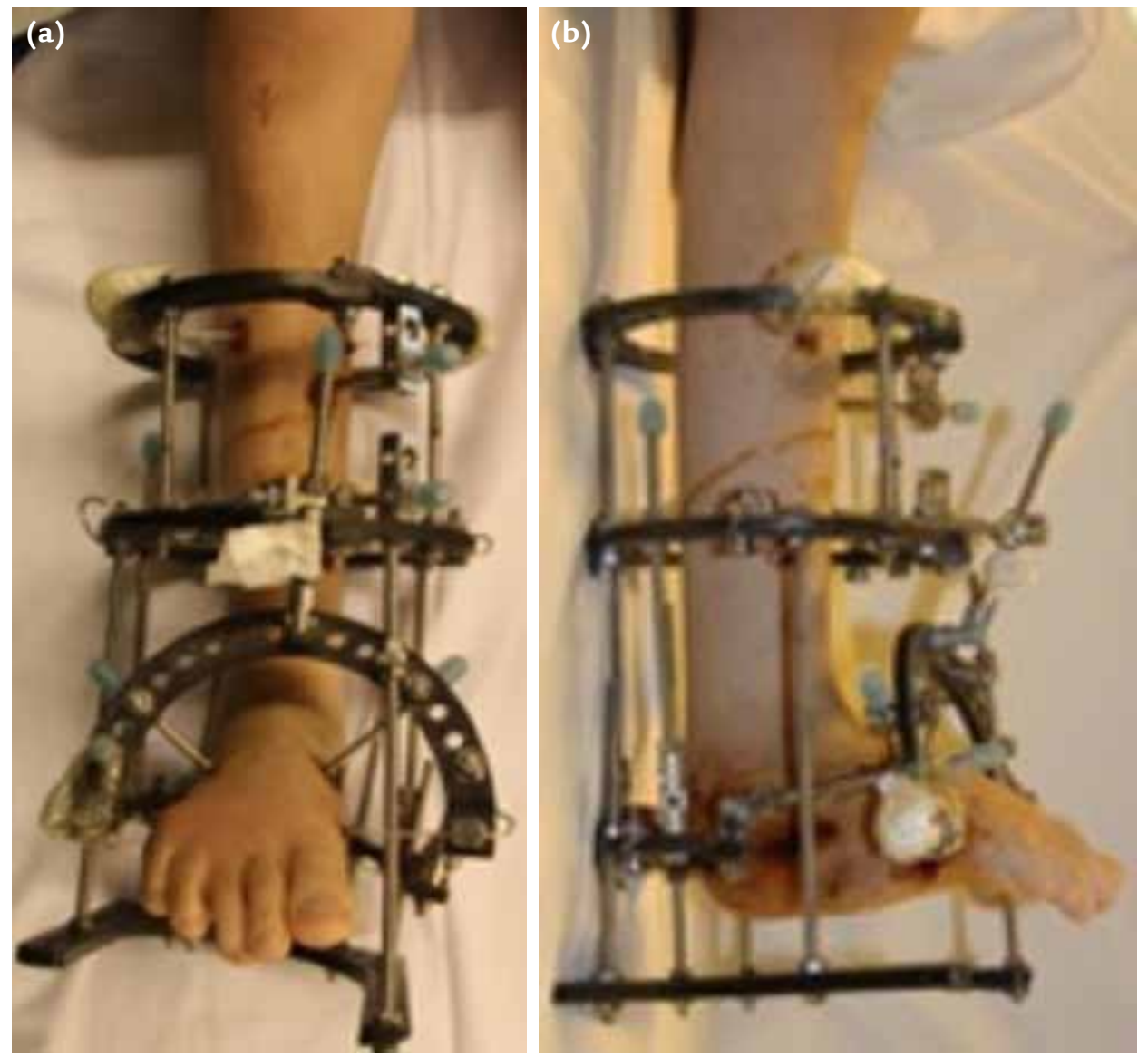

Şekil 3. a, b. Ilizarov eksternal fiksatörünün önden (a) ve yandan (b) görünümleri.

deformitesi, yumuşak dokuların el verdiği ölçüde akut olarak düzeltilirken, ayak arkası varusu ve ekinus tedrici olarak düzeltilmelidir. Ayağın arka kısmının düzeltilmesi, arkadaki iki rodun uzatılmasıyla sağlanırken, mediyal ve lateraldeki rodlar ekinusu ve varusu düzeltir.

Bilgisayar destekli sistemler, ortopedi pratiğinde kullanılır hale gelmelerini takiben, kompleks ayak deformitelerinin tedavisinde de etkili bir seçenek olmaya başlamıştır. Bu amaçla, eksternal fiksatör kurulumu, standart halka, miter ve butt frame olarak tanımlanmıştır. Ancak, hastanın ihtiyacına göre eksternal fiksatör kurulumunda değişikliğe gidilebilir (Şekil 4).

Distraksiyon işlemine, cerrahiyi takiben bir-iki gün içinde başlanır; günde dört seferde, toplam 1-2 mm distraksiyon yeterli olur. İstenilen düzeltmenin elde edilmesinden sonra, frame beş-altı hafta daha kalmalı ve sonrasında dört-altı hafta süre ile, yürüme alçısı uygulanmalı ve gerekli hallerde bir yıl kadar AFO (AnkleFoot-Orthosis) cihazı ile ayak ve ayak bileği pozisyonu korunmalıdır.

\section{TEDAVIDE YAŞANAN GÜÇLÜKLER VE KOMPLIKASYONLAR}

Literatürdeki tüm eksternal fiksatör uygulamalarında olduğu gibi, doğuştan çarpık ayağın eksternal fiksatör ile tedavisi de birçok güçlüğü ve komplikasyonu bünyesinde barındırmaktadır. Uzun tedavi süresi, pin dibi enfeksiyonu, parmak kontraktürleri, distraksiyonun yarattığı ağrı, damar-sinir yaralanması, cilt nekrozu, deformitenin nüks etmesi, hareket kısıtlılığı, yetersiz-aşırı düzeltme, osteoporoz, spontan ankiloz ve erken osteoartrit, bu noktada ilk akla gelenlerdir. ${ }^{[3]}$

Pin dibi enfeksiyonu, genellikle yara bakımı ve uygun antibiyoterapi vasıtasıyla tedavi edilebilmektedir. Pençe ayak deformitesi (claw foot) gelişmemesi için bantlama ve fizik tedavi, eğer deformite gelişmişse tenotomi ve Kirschner teli ile tespit uygulanmaktadır. Distraksiyonun yarattığı ağrı ve ilişkili olabilecek damar sinir yaralanmaları hususunda dikkatli olunmalı, hastalar tedavi boyunca sıkı takip edilmelidirler. Ayak 

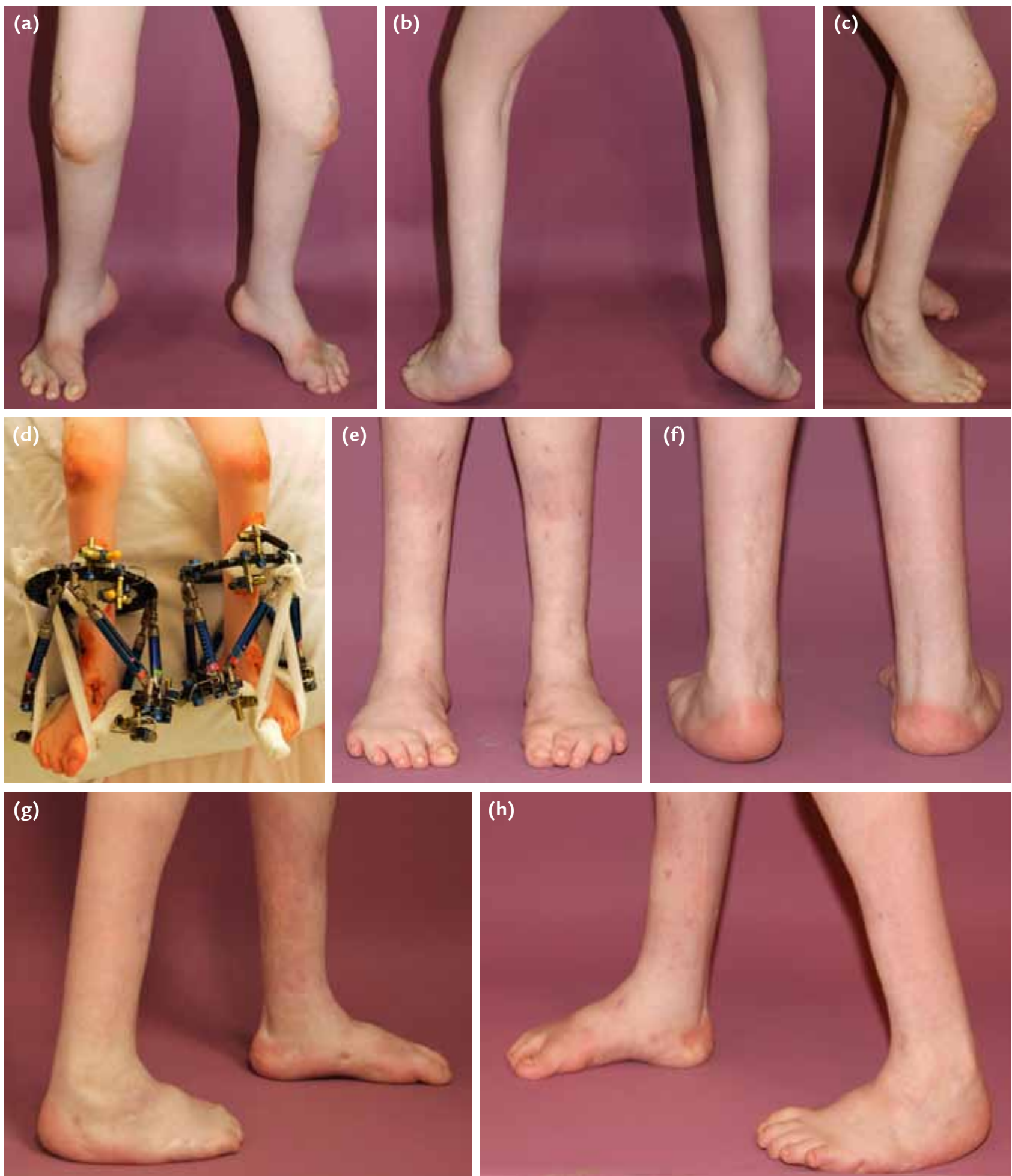

Şekil 4 a-h. Artrogripozise bağlı doğuştan çarpık ayak olgusunun önden (a), arkadan (b), dış yandan (c); bilgisayar destekli eksternal fiksatör ile düzeltilmesi ardından, ameliyat sonrası (d), fiksatör çıktıktan sonra önden (e) arkadan (f), sağ yandan (g) ve sol yandan (h) görünümleri. 

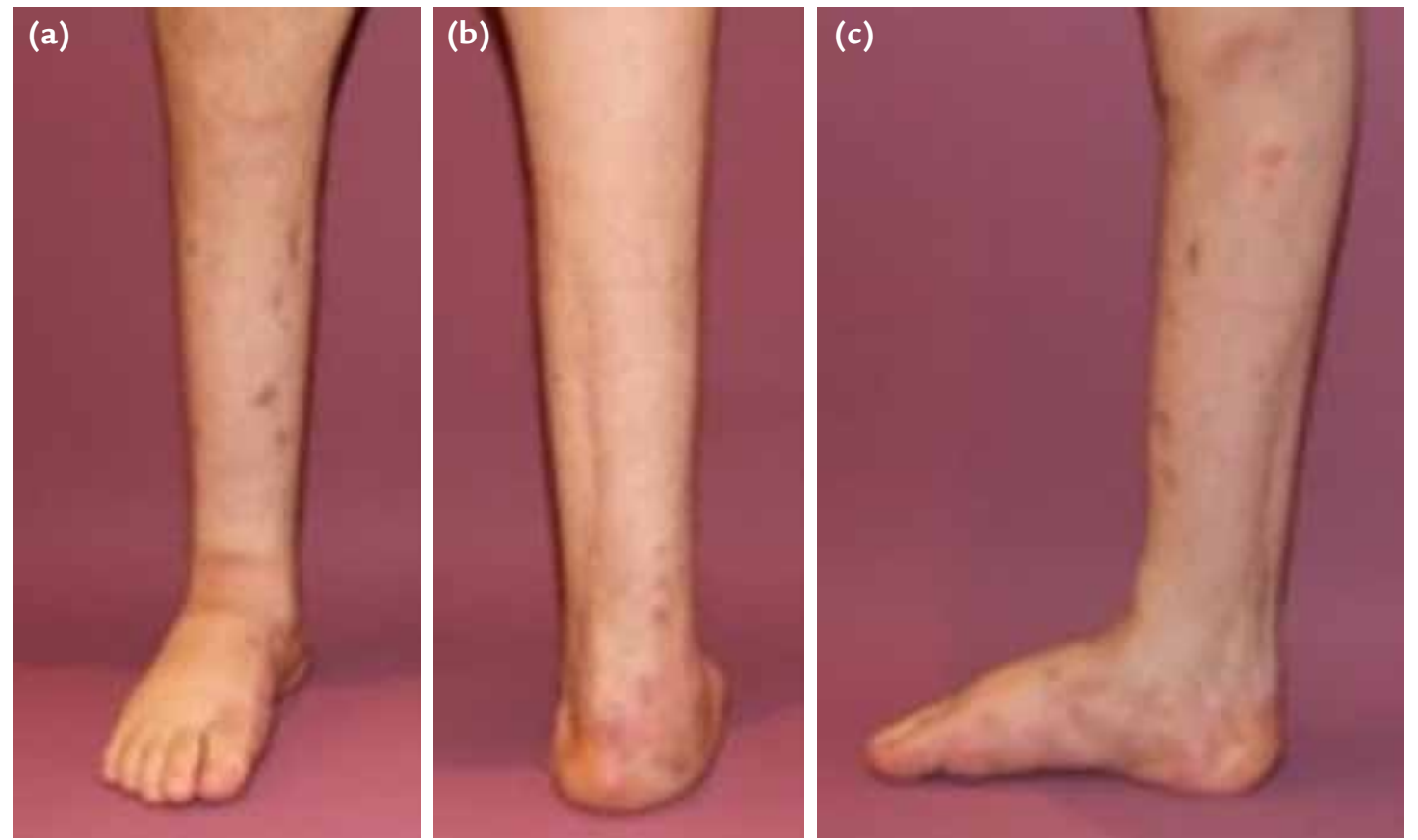

Şekil 5. a-c. Ilizarov eksternal fiksatörü çıkarıldıktan sonra ayak ve ayak bileğinin önden (a), arkadan (b) ve iç yandan (c) görünümleri.

bileği ve ayağın posteromediyali, cilt nekrozunun görülmesi en muhtemel olduğu bölgeler olarak göze çarpar ve böyle bir durumla karşı karşıya kalındığında, ilk olarak düzeltme hızı düşürülmeli, gerekirse düzeltmeye ara verilmelidir. Aynı şekilde, talar subluksasyon, distal tibial epifizin lizisi ve başta birinci parmak olmak üzere metatarsofalengeal eklem subluksasyonu açısından da, hastalar sıkı klinik ve radyografik gözleme tabi tutulmalıdırlar. Metatarsofalengeal eklem subluksasyonunun tedavisinde, periartiküler yumuşak doku gevşetmesi ve Kirschner teli ile tespit uygulanmaktadır. Çarpık ayak deformitesinin nüksü, açık cerrahide olduğu gibi eksternal fiksatör yöntemiyle tedavi sonucunda da karşılaşabileceğimiz sorunlardan biridir. En sık görülen nüks biçimi, ekinokavus, ekinovarus ve adduksiyon/supinasyondur. ${ }^{[5]}$ Ekinus deformitesinin nüks etmesinde en önemli etken, fiksatör kullanılmasını takiben giyilen bot ya da cihazların yeterli topuk desteğini sağlayamamasıdır. Bu noktada, uzun süreli AFO cihazı kullanımı (eksternal fiksatörün çıkarılmasını takiben yaklaşık bir yıl kadar) vasıtasıyla düzeltmenin korunması, önemini hala korumaktadır. Özellikle ayak bileği anterior-posterior kas dengesizliğinden dolayı, adduksiyon ve supinasyon deformiteleri oluşabilir ve ayak - ayak bileğine yönelik artrodezler (Chopart artrodez, subtalar artrodez, üçlü artrodez ve tibiotalar artrodez), tedavide başvurulan yöntemlerdir. Hastalığın bir sonucu olan flat-top talus deformitesi, tedavi sonucunda da karşımıza çıkabilmektedir. Tedavide ise, distal tibia supramalleoler osteotomisi vasıtasıyla, hem ekinus deformitesi düzeltilmekte hem de anterior ayak bileği sıkışmasının önüne geçilerek daha geniş bir eklem hareket aralığı sağlanması hedeflenmektedir. Eklem hareket kısıtlılığı - eklem sertliği tedavi sürecinin uzunluğu, altta yatan ankiloz varlığı gibi faktörlerden etkilenir. Bu noktada, tedavinin aşamalarına uygun olacak şekilde fizik tedavi görülebiliyor olması büyük önem arz eder.

\section{SONUÇ}

Doğuştan çarpık ayak tedavisinde amaç, tabanı yere basabilen, hareketli ve ağrısız bir ayak elde edilmesidir (Şekil 5). Konvansiyonel yöntemlerin geniş ve çoğu zaman tekrarlayan yumuşak doku ve kemik cerrahilerini içeriyor olmaları ve yüksek nüks oranları göz önüne alındığında, tedrici distraksiyon vasıtasıyla eklem-kemik diziliminin yeniden sağlanmasını esas alan eksternal fiksatör ile, tedrici düzeltme önemli bir tedavi seçeneği olarak görülebilir. Doğuştan çarpık ayak tedavisinde eksternal fiksatör kullanımının, minör komplikasyon oranıyla beraber, klinik ve radyografik olarak etkin bir yöntem olduğu, birçok çalışma ile gösterilmiştir. ${ }^{[2,7-15]}$ 


\section{KAYNAKLAR}

1. Morcuende JA, Dolan LA, Dietz FR, Ponseti IV. Radical reduction in the rate of extensive corrective surgery for clubfoot using the Ponseti method. Pediatrics 2004;113(2):376-80.

2. Bradish CF, Noor S. The llizarov method in the management of relapsed club feet. J Bone Joint Surg Br 2000;82(3):387-91.

3. Ganger R, Radler C, Handlbauer A, Grill F. External fixation in clubfoot treatment - a review of the literature. J Pediatr Orthop B 2012;21(1):52-8. CrossRef

4. Paley D. The correction of complex foot deformities using Ilizarov's distraction osteotomies. Clin Orthop Relat Res 1993;(293):97-111.

5. Ferreira RC, Costa MT. Recurrent clubfoot -approach and treatment with external fixation. Foot Ankle Clin 2009;14(3):435-45. CrossRef

6. Burns JK, Sullivan R. Correction of severe residual clubfoot deformity in adolescents with the Ilizarov technique. Foot Ankle Clin 2004;9(3):571-82.

7. El-Mowafi H, El-Alfy B, Refai M. Functional outcome of salvage of residual and recurrent deformities of clubfoot with Ilizarov technique. Foot Ankle Surg 2009;15(1):3-6. CrossRef

8. Prem $\mathrm{H}$, Zenios M, Farrell R, Day JB. Soft tissue Ilizarov correction of congenital talipes equinovarus -5 to 10 years postsurgery. J Pediatr Orthop 2007;27(2):220-4.
9. Saghieh S, Bashoura A, Berjawi G, Afeiche N, Elkattah R. The correction of the relapsed club foot by closed distraction. Strategies Trauma Limb Reconstr 2010;5(3):127-35. CrossRef

10. Lamm BM, Standard SC, Galley IJ, Herzenberg JE, Paley D. External fixation for the foot and ankle in children. Clin Podiatr Med Surg 2006;23(1):137-66.

11. Tripathy SK, Saini R, Sudes P, Dhillon MS, Gill SS, Sen RK, Agarwal A, Dhatt S, Mootha AK. Application of the Ponseti principle for deformity correction in neglected and relapsed clubfoot using the Ilizarov fixator. J Pediatr Orthop B 2011;20(1):26-32. CrossRef

12. Kocaoğlu M, Eralp L, Atalar AC, Bilen FE. Correction of complex foot deformities using the Ilizarov external fixator. J Foot Ankle Surg 2002;41(1):30-9.

13. Weber $M$, Schwer $H$, and Zilkens KW, Siebert CH. Tibiocalcaneo-naviculo-cuboidale arthrodesis: 6 patients followed for 1-8 Years. Acta Orthop Scand 2002;73(1):98-103.

14. Lohia LK, Meena S, Kanojia RK. Comparative study of complete subtalar release and Joshi's external stabilization system in the management of neglected and resistant idiopathic clubfoot. Foot Ankle Surg 2015;21(1):16-21. CrossRef

15. El-Sayed M. Ilizarov external fixation for management of severe relapsed clubfeet in older children. Foot Ankle Surg 2013;19(3):177-81. CrossRef 